\title{
Income Generating Activities of Rural Kenyan Women
}

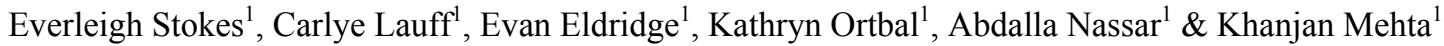 \\ ${ }^{1}$ Humanitarian Engineering and Social Entrepreneurship (HESE) Program, School of Engineering Design, \\ Technology, and Professional Programs (SEDTAPP), The Pennsylvania State University, United States
}

Correspondence: Khanjan Mehta. E-mail: khanjan@engr.psu.edu

$\begin{array}{lc}\text { Received: February 28, } 2015 & \text { Accepted: June 17, } 2015 \text { Online Published: September 27, } 2015 \\ \text { doi:10.5539/jsd.v8n8p42 } & \text { URL: http://dx.doi.org/10.5539/jsd.v8n8p42 }\end{array}$

\begin{abstract}
The proportion of female-headed households is rising dramatically in sub-Saharan Africa, making women's income generating activities an increasingly important area of study. As women transition into the role of head-of-household, their traditional activities are augmented with the responsibility of being the breadwinner, and their successes become inextricably linked to the wellbeing of the entire household. In order to create sustainable development programs and policies that support women in this new role, an understanding of women's current income generating activities must be established. This article seeks to do that through answering two questions. First, how do rural Kenyan women earn a livelihood? And second, what influences a woman's decision to spend time, sweat, and energy on certain income-generating activities? The findings suggest that there are several underlying factors influencing women's livelihoods and livelihood-related choices. Some of these factors include prioritizing relationships over occupation, identifying positive factors about their current income generating activities (i.e. comfort, extra food, flexible schedule), and planning for dependents rather than themselves. Moreover, the level of education and number of income generating activities directly impact the total income. These findings allow us to better understand the motivations and influences over the choices of work, as well as initiate a conversation on micro franchise opportunities in developing nations.
\end{abstract}

Keywords: entrepreneurship, developing nations, female headed households, income generating activities, mico franchise, rural Kenya, social franchise, sub-Saharan Africa, women

\section{Introduction}

\subsection{Increase in Female-Headed Households}

The percentage of female-headed households in East Africa is increasing dramatically. In 1989, Jiggins reported that $30 \%$ of the rural households across sub-Saharan Africa were female-headed, while in 2011 the International Fund for Agricultural Development published figures showing that up to $60 \%$ of rural households in the same area were female-headed. This increase is indicative of a shift in the way households and income-generating activities work in East Africa, and cannot be ignored. It is clear that the successes of sustainable development related projects and policies in East Africa are, at least partially, dependent on women's success as they transition into the important role of primary wage-earner.

In order to successfully make the transition from household member to head of the household, women must augment their traditional roles as primary caregivers and producers of food crops, with the ever-important role of breadwinner. To generate the financial assets necessary to provide for their households in rural underserved communities with weak economies, women engage in a variety of activities. They are not averse to working multiple jobs in addition to working within the home, but their primary incentive is subsistence. Expenditures are dedicated first to the basic survival of the household, and the majority are dedicated to sustenance-related purchases such as food. Once they reach a level of subsistence, women may acquire an asset, such as an animal, which will serve as security, but studies in West Africa suggest that women rarely reach a level where they engage in risky income generation activities such as entrepreneurship or social enterprise (Zulu, 2011).

The increasing percentage of female-headed households is not a new phenomenon; it has been of great interest to economists, academics, and program and policy makers for the last forty years. In their 1978 manuscript, Women-headed household; the ignored factor in development planning, Buvinic, Youssef, and Von Elm (1978) first brought the issue of the increasing prevalence of female-headed households across the developing world to the forefront of the field of international sustainable development. They estimated that $22 \%$ of households in 
sub-Saharan Africa were currently, or had the potential to become, female-headed households. Eleven years later, Jiggins (1989) published figures showing that up to $30 \%$ of households in Sub-Saharan Africa were female-headed, and in 2011 that percentage was further increased to 60\% through research from the International Fund for Agricultural Development (IFAD, 2011). The increasing percentage of female-headed households marks a shift in the way that households in the developing world function and ultimately signifies an increasing number of households with fewer resources who are more vulnerable to fiscal shock and poverty. This vulnerability related to women's position in the developing world has been clearly articulated as the "feminization of poverty."

By the 1990's, the "feminization of poverty" and its consequences had become a heavily discussed topic amongst economists, and although the specific consequences of belonging to a female-headed household are still somewhat debated, there is wide consensus that female-headed households in developing countries deserve special attention (Chant, 2008). These households typically have less access to land, credit, and the labour market than male-headed households, are more susceptible to fiscal shock, and more likely to experience extreme poverty (King et al., 2008). Additionally, female-heads face the "double day burden" of needing to serve as the breadwinner and primary caretaker of the household (World Bank, 2009). In many ways, female-headed households represent a critical and at-risk demographic that continues to grow in importance. It's clear that the successes of sustainable development related projects and policies in East Africa are, at least partially, dependent on women's success as they transition into the important role of the head of the household.

\subsection{Challenges with Expansion of Women's Traditional Roles}

In order to successfully transition into the role of head of the household, women must take on a number of new responsibilities in addition to their traditional roles as primary care givers and agricultural workers. Women, despite their disadvantageous position, must now take on the role of the breadwinner, and it is not an easy transition; women face many challenges when it comes to making an income sufficient to support their household. First, women living in rural underdeveloped areas have minimal access to land-a critical component of agriculture on which $80 \%$ of rural households depend for their livelihoods (FAO, 2008). Women also have limited access to formal credit due to the fact that they are less likely to have access to the collateral (such as land) needed for approval (King et al. 2008). Finally, women are both less likely to have adequate access to the established labour market and less likely to seek out entrepreneurial opportunities. Causes of this discrepancy include, but are not restricted to, gender discrimination, societal norms, and availability during formal working hours (World Bank, 2012). Terrell and Troilo (2010) further suggest that due to the influence of patriarchal society, women are less likely than men to hold the work values of initiative, achievement, and respect (which are positively correlated with entrepreneurship). With a perception that men should be dominant, women tend to look to become salaried employees instead of entrepreneurs, but with limited access to the established labour market, they are often forced to take on several informal jobs instead of dependable salaried positions. Women often work long hours in addition to their duties inside the home for a limited income, and thus their first priority is subsistence.

For many female-headed households expenditures are restricted to the basic survival of the household, the majority being sustenance-related, such as the purchase of food. Once women are able to bring their households to a level of subsistence they may acquire an asset, such as an animal, to serve as security. However, studies in West Africa suggest that women rarely reach a point where they will engage in risky income generation activities such as entrepreneurship (Zulu, 2011). Barriers to entrepreneurship, especially for women, are many and complex in the developing world. Although Schreiner and Waller (2003) suggest that succeeding as an entrepreneur in the developing world can be easier than in the developed world due to lower standards and less complexities, women are still $30 \%$ more likely than men to close a personal business. Women face barriers, moreso than men, that go beyond gaining access to land, credit, and the labour market (Bakesha et al, 2009).

The transition from household member to head of the household requires time. Socially, women must balance household and maternal responsibilities with income generating activities. Often, starting a business requires more time than many women can give. In addition, financially supporting their households significantly limits the amount of excess capital available to finance start-ups. Most women have also not obtained the proper education or developed the necessary skill-set to run their own businesses (Francis, 2002). Agricultural ventures, which are of particular interest to women since they are traditionally responsible for the production of food crops, are impacted by environmental and geographical factors beyond women's control. Environmentally, variations in climate across the seasons create fluctuating customer interest, impacting already fragile supply and demand systems. Geographically, physical characteristics inhibit the diversification of crop production, so women face high competition in local markets and little ability to pivot to new markets (Quisumbing \& Pandolfelli, 2009). 
However, there is great merit in entrepreneurship, and it is widely cited as a way for entire households to move from subsistence to sustainability.

\subsection{Value of Entrepreneurship}

Entrepreneurship has the potential to facilitate the successful transition of women into their new roles and to help their households thrive. There are additional merits to entrepreneurship; new business ventures facilitate the delivery of new products and services, which make local economies more robust and resilient (Banerjee \& Duflo, 2007). Women entrepreneurs are also more likely to list social impact as a goal of their business (Terjesen \& Elam, 2012). In order to strengthen women's current livelihoods, increase female participation in the field of entrepreneurship, and ultimately see the success of women-headed households, programs are needed that adequately address their unique needs.

Programs and processes have been developed to assist women in overcoming social, economic, environmental, and cultural barriers associated with entrepreneurship. One contemporary solution targeting increased education and training is the Women Entrepreneurship Program started in South Africa in 2007 (Botha et al., 2007). Micro-finance institutions also encourage women's participation. These institutions serve the poor in under-developed communities by providing loans and overall access to capital. Micro-finance institutions are often paired with social franchising opportunities, which allow women to engage in entrepreneurial activities at their convenience with initiative.

Social franchising creates an entrepreneurial framework that provides women autonomous opportunities to make money while leveraging and building their social networks. The mission of these social franchises is two-fold. First, they strive to create social impact and solve a communal problem, such as low access to healthcare or food insecurity. Secondly, instead of simply offering means of employment and income, social franchising ventures establish secure, sustainable and scalable frameworks for the women to work within (Alur \& Schoormans, 2011). Through social franchises women receive tools, guidance, and credibility from the overarching business while maintaining the freedom to put as much time and energy into the work as they choose. Such opportunities are becoming increasingly popular as a tool to empower women and create opportunities for entrepreneurship in the developing world as they bridge many of the difficulties traditionally faced by female heads of household.

In order to support similar programs like these in the future, it is key to understand what rural female-headed households are currently doing to earn an income and what motivates women to engage in certain activities over others. By ascertaining the answers to these questions, programs can better address macro-level questions, such as how to engage women in innovative income-generating activities and how to best develop practical and appealing entrepreneurial opportunities. These opportunities can then empower women to build healthy, resilient families and successfully transition from household member to head of the household.

Entrepreneurship is widely considered a viable method for moving rural households from subsistence to sustainability (Cukier et al., 2011). New business ventures make local economies more robust and resilient. Additionally, women entrepreneurs are more likely to list social impact as a goal of their business (Terjesen \& Elam, 2012). In order to strengthen women's current livelihoods, increase female participation in the field of entrepreneurship, and ultimately see the success of women-headed households, it is key to understand what rural female-headed households are currently doing to earn an income and what motivates women to engage in certain activities over others.

This article attempts to understand the current circumstances of female-headed household's income generating activities by answering two questions: 1) how do rural Kenyan women earn a livelihood? and 2) what influences a woman's decision to spend time, sweat, and energy on certain income-generating activities? This article describes the prevalence of female-headed households and the challenges women face with increased responsibility. It goes on to present data regarding the income generating activities and inherent challenges reported by women in rural Kenya, and the influence of factors such as the number of dependents, education level, and social network, on women's decisions to become entrepreneurs. Finally, conclusions are established that provide a better understanding of how these factors can inform the development of entrepreneurial ventures, and suggestions are posed for leveraging the power of micro-franchising to empower female-headed households by improving women's livelihoods in a self-determined manner. 


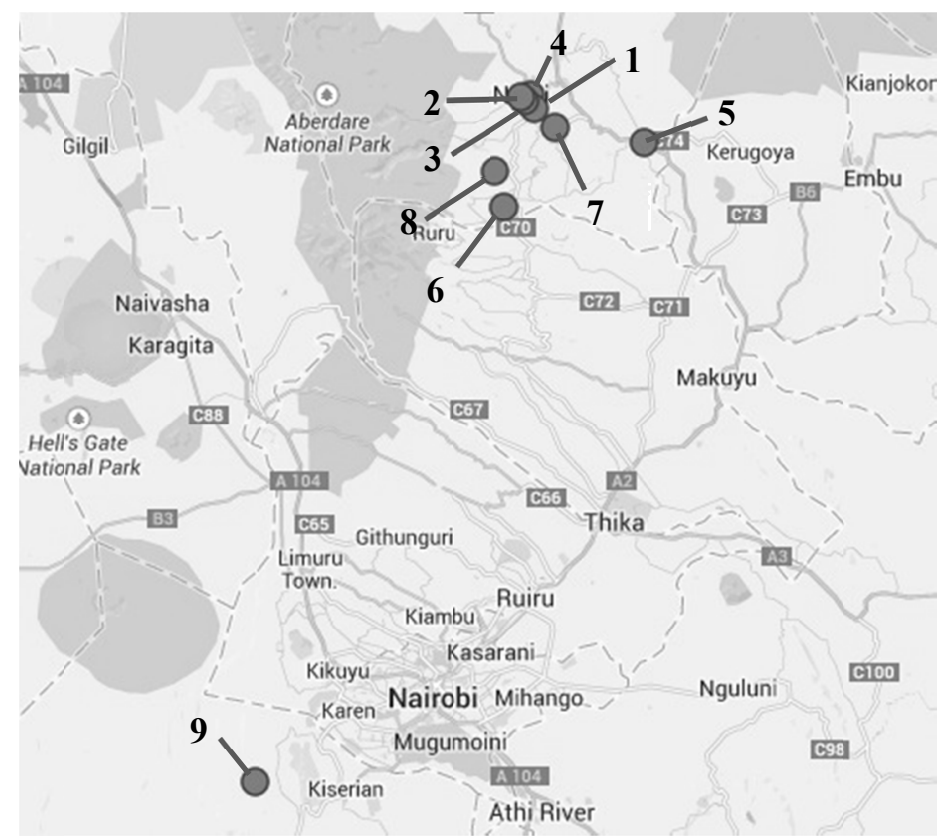

Figure 1. Research locations in and around Nyeri, Kenya

\section{Method}

\subsection{Research Location and Participants}

Research was conducted in and around Nyeri, Kenya, a town of 120,000 citizens located approximately three hours north of the Kenya's capital city Nairobi. All 173 participants were randomly selected, distributed as follows and geographically referenced in Figure 1: 9 participants in the town of Skuta (1), 44 in Nyeri Town (2), 37 in the slum of Mejango (3), 34 in the neighbourhood of King'ong'o (4), 21 in the town of Karatina (5), 3 in the town of Gichiche (6), 18 in the town of Gatitu (7), 5 in Kagonye (8), and 2 in Watitu (9).

The researchers aimed to interview women who worked in a multitude of different occupations, and systematically identified women who could give the data more robustness through this variety of income generating activities. Women were usually interviewed in their work location, but some were also interviewed near their homes or in public areas.

\subsection{Interview Procedure}

All 173 interviews were collected in 9 towns over 3 weeks during the summer of 2013. The interviews were conducted with the aid of local Kenyan interpreters. The participants were read an overview summary of the research study, and they were given the opportunity to decline being interviewed before beginning. The interview protocol was developed in advance, with 6 major questions and 11 additional probing questions under them. Interviews were conducted informally, acting more as a conversation with the women rather than a structured set of questions. More valuable information was gained through the richness of the stories the women shared. These interview conversations were recorded with an audio-recorder and field notes were also taken. The full roster of questions can be found below:

1) What is your main source of income?
a. How many hours per day do you work?
b. How many days per week do you work?
c. How any shillings do you make per week?
d. What are some challenges you face with this job?

2) Secondary source of income?
a. How many hours per day do you work?
b. How many days per week do you work?
c. How any shillings do you make per week?

3) What are some challenges you face with this job? 
4) How many people do you provide for?
a. What are your monthly expenses?
b. Do you have money left over at the end of each month?
c. Do you save money?

5) What is the highest level of education you have achieved?

6) What is your dream job?

a. Why do you aspire to have such a job?

Answers to all of these questions were collected and then digitally entered into our database system each evening. Participants remained anonymous and were identified numerically and by their income generating activities. This data collection method allowed for both quantitative and qualitative analysis. The data was analyzed statistically to provide insights into positive correlations between factors. Additionally, portions of conversation were transcribed and used for qualitative coding, which provided insights into the reasoning behind each of the income generating activities.

We acknowledge the limitations of the research conducted, including the small sample size, the language and dialect barriers, and the use of interpreters. To mitigate these limitations, women were selected at random and interpreters were closely monitored. Any interviews with known interpreter error were removed, and it is not believed that valuable information was lost in interpretation.

\section{Results}

\subsection{Common Income Generating Activities}

Table 1 shows the income generating activities reported by women along with the total count of women who reported participation in that activity. Several of the job titles were condensed for analysis. For example, workers in hotels and resorts were grouped together due to similarities in employees' responsibilities and income. The descriptions were developed through observations and conversations with individuals in the respective roles. Additionally, the challenges listed are those explicitly identified by Kenyan women during the interview process. Many women also self-reported simultaneous participation in two or three income generating activities in order to earn an ample income.

Table 1. Common income generating activities of rural Kenyan women

\begin{tabular}{|c|c|c|c|c|}
\hline & Job Title & Count & Job Description & Reported Challenges \\
\hline 1 & Produce Seller & 29 & $\begin{array}{l}\text { A produce seller rents out a wooden station in the town } \\
\text { market where they sell fruits and vegetables. }\end{array}$ & $\begin{array}{l}\text { - } \text { Hard to get customers } \\
\text { - } \quad \text { Local council (rent, rules) } \\
\text { - } \text { - } \text { No expertise in field } \\
\text { - } \text { Weather } \\
\text { - } \quad \text { Location of selling } \\
\text { - } \text { Capital to buy goods } \\
\text { - } \quad \text { Produce rotting } \\
\text { - } \text { Daily routine boring } \\
\text { - } \text { Competition is high } \\
\text { - } \quad \text { Not paid well }\end{array}$ \\
\hline 2 & Clothes Washer & 30 & $\begin{array}{l}\text { A woman who washes clothes must seek out customers } \\
\text { and wash and dry their clothes, sometimes in a river or } \\
\text { with whatever water she can find. }\end{array}$ & $\begin{array}{l}\text { - } \begin{array}{l}\text { Too much work for too } \\
\text { little earning }\end{array} \\
\text { - People don't pay well due } \\
\text { to social status } \\
\text { - Finding } \\
\text { inconsistency customers, } \\
\text { - Employer not paying } \\
\text { enough } \\
\text { - Gets sick from too much } \\
\text { work/wash water } \\
\text { - Customers complaining } \\
\text { Not paid on time }\end{array}$ \\
\hline
\end{tabular}




\begin{tabular}{|c|c|c|c|c|}
\hline 3 & Cook & 4 & $\begin{array}{l}\text { A cook works in a hotel (restaurant) and prepares the food } \\
\text { for the customers to eat. }\end{array}$ & $\begin{array}{ll}\text { - } & \text { Difficult to get job } \\
\text { - } & \text { Overworked } \\
\text { - } & \text { Injury-prone }\end{array}$ \\
\hline 4 & $\begin{array}{l}\text { Worker in } r \\
\text { (restaurant) } \text { or } \\
\text { (hotel) }\end{array}$ & 21 & $\begin{array}{l}\text { This worker is required to report to a higher authority in } \\
\text { the hotel or resort and carry out duties prescribed to them, } \\
\text { i.e. waiting tables, working front desk, cleaning rooms. }\end{array}$ & $\begin{array}{ll}\text { - } & \text { Hard to get customers } \\
\text { - } & \text { Body pain from long days } \\
\text { - } & \text { Thieved, abused, harassed } \\
\text { - } & \text { Not paid on time } \\
\text { - } & \text { Customers can be rude }\end{array}$ \\
\hline 5 & Cereal Seller & 7 & $\begin{array}{l}\text { A cereal seller rents out a wooden station in the town } \\
\text { market where they sell grains and beans. }\end{array}$ & $\begin{array}{ll}\text { - } & \text { Hard to get customers } \\
\text { - } & \text { Expensive to buy cereals } \\
\text { - } & \text { Seasonal } \\
\text { - } & \text { Local council rules }\end{array}$ \\
\hline 6 & Market Vendor & 6 & $\begin{array}{l}\text { A market vendor rents out a wooden station in the town } \\
\text { market and streets where they sell goods. }\end{array}$ & $\begin{array}{ll}\text { - } & \text { Local council } \\
\text { - } & \text { Health problems } \\
\text { - } & \text { Location of booth } \\
\text { - } & \text { Capital to purchase goods } \\
\text { - } & \text { Customers complaining }\end{array}$ \\
\hline 7 & Salon & 14 & $\begin{array}{l}\text { A salon worker must wash and style other women's hair } \\
\text { to their pleasing. }\end{array}$ & $\begin{array}{ll}\text { - } & \text { Customers complaining } \\
\text { and not paying } \\
\text { - } & \text { Not consistent customers } \\
\text { - } & \text { Talent/expertise required } \\
\text { - } & \text { Service on credit then not } \\
\text { paying } \\
\text { - } \text { Weather } \\
\text { - Customers missing } \\
\text { - } \text { appointments } \\
\text { - } \text { Loctricity for machines } \\
\text { - }\end{array}$ \\
\hline 8 & Food Vendor & 9 & $\begin{array}{l}\text { A food vendor can either sell cooked food items in a cart } \\
\text { walking around town or at their small stand in town. }\end{array}$ & $\begin{array}{ll}\text { - } & \text { Lack of customers } \\
\text { - } & \text { Tiresome } \\
\text { - } & \text { City Council } \\
\text { - } & \text { Food going bad } \\
\text { - } & \text { Time to cook/prepare } \\
\text { - } & \text { Location }\end{array}$ \\
\hline 9 & Tailor & 7 & $\begin{array}{l}\text { A tailor is responsible to hemming, altering, and making } \\
\text { clothing for customers. }\end{array}$ & $\begin{array}{ll}\text { - } & \text { Getting customers } \\
\text { - } & \text { Not paying for services } \\
\text { - } & \text { Customers complaining } \\
\text { - } & \text { Buying materials }\end{array}$ \\
\hline 10 & Farm Labourer & 45 & $\begin{array}{l}\text { A farm labourer is someone who works on either a small } \\
\text { farm (garden) or a larger farm and works to plant, sow, } \\
\text { tend, and pick the end crops to sell. }\end{array}$ & $\begin{array}{ll}\text { - } & \text { Tiresome, lack of } \\
\text { - } & \text { man-power } \\
\text { - } & \text { Weather/Climate } \\
\text { - } & \text { Seasonal items } \\
\text { - } & \text { Injury prone } \\
\text { - } & \text { No break for mid-meals } \\
\text { - } & \text { Lack of capital to expand } \\
\text { - } & \text { Space to grow } \\
\text { - } & \text { Low cost to sell goods } \\
\text { - } & \text { Hard to get job } \\
\text { - } & \text { Pests, soil, water problems } \\
\text { - } & \text { Looked down upon }\end{array}$ \\
\hline 11 & Hawker & 3 & $\begin{array}{l}\text { A hawker is a person who does not buy a permit, but } \\
\text { rather walks in town and down streets trying to sell items } \\
\text { in their hand to passer-byers. }\end{array}$ & $\begin{array}{l}\text { - Local Council } \\
\text { - Selling on credit and never } \\
\text { getting paid } \\
\text { - Ignorance from customers }\end{array}$ \\
\hline
\end{tabular}


12 Boutique Seller

A boutique seller is someone who sells clothing or other household goods at a wooden stand in the clothing market place.

- Competing sellers, must sell at low price

- Lack of customers

- Lots of idle time

- Capital to purchase goods

- Quality of goods not always high

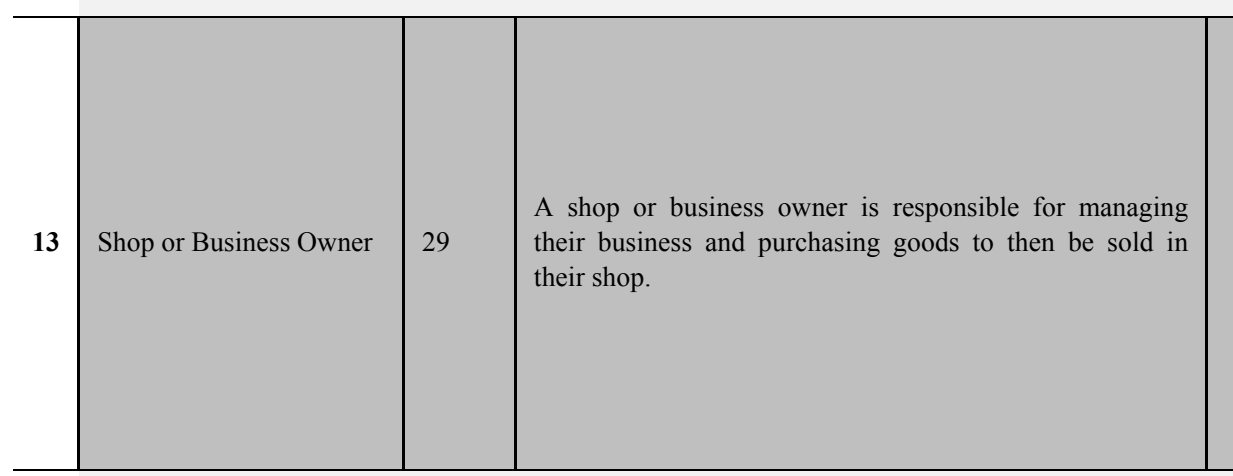

- Can be weather dependent

- Perishable goods

- Lack of customers

- Capital to expand

- Paying on credit then not paying in full

- Rising prices of goods

- Rent and taxes

- Local council

- Business is slow at times

- Angry customers

- Controlling kids

- Hard to get money from parents

A teacher works in an elementary or high school and teaches students subjects to help them train to then go out and work.

- Stressful

- Not being paid in good time

- Not having students get jobs

\begin{tabular}{l|l|l|l|}
\hline 15 & Street Cleaner & 2 & A street cleaner is someone who cleans the streets in town. \\
\hline
\end{tabular}

- Social status

- Lack of customers

- Having someone to report to

- Sometimes irrational duties

Employee (of shop/store, An employee of a store or hotel is someone who works for hotel, bar) $13 \quad$ a higher authority and must complete the tasks assigned to them, i.e. cleaning, selling, waiting on customers)

- People paying on credit then not paying in full

- Angry customers

- Can be paid on commission only

\begin{tabular}{l|l|l|l}
\hline 17 & Guard & 1 & $\begin{array}{l}\text { A guard is someone who protects an entity, like a bank, } \\
\text { from outside enemies. }\end{array}$
\end{tabular}

Community Health

18 Worker (CHW) or Mashavu Health Worker (MHW)
A CHW is someone in the community who is paid a stipend to go around and teach other about being health. An MHW is a trained CHW who then also gets paid for providing basic pre-primary health services to customers.

\begin{tabular}{l|l|l|}
\hline 19 & Wholesaler & 1 \\
\hline
\end{tabular}

20 Dancer

$1 \quad 10$

1
A wholesaler is someone who buys cereals (grains) in
massive quantities and then sells to the lower "cereal
sellers" in the market.

A dancer is someone who is paid to perform at a venue in town, often with cultural or spiritual rituals.
- Do not know where enemies might be

- Mostly volunteering, very low stipend

- Hard to find people who want to learn and listen

- Not given time to talk to groups

- People not understanding procedure

- $\quad$ Range of daily money

- None stated

- Obtaining proper training

21 Housewife

A housewife is responsible for the care and up-keep of the family house, which can contain washing clothes, cooking, and working in the garden.
- Don't have money

- Can't find a job

- No time to have a job 


\begin{tabular}{|c|c|c|c|c|}
\hline 22 & Unemployed & 2 & $\begin{array}{l}\text { Someone who is unemployed does not work either due to } \\
\text { lack of finding a job or because her husband will not let } \\
\text { her work. }\end{array}$ & $\begin{array}{l}\text { - Not allowed to work from } \\
\text { husband }\end{array}$ \\
\hline 23 & Charcoal Seller & 1 & $\begin{array}{l}\text { A charcoal seller rents out a wooden station in the town } \\
\text { market where they sell charcoal. }\end{array}$ & $\begin{array}{ll}\text { - } & \text { Boredom } \\
\text { - } & \text { Health issues } \\
\text { - } & \text { Local council } \\
\text { - } & \text { Lack of capital }\end{array}$ \\
\hline
\end{tabular}

\subsection{Hierarchy of Income Generating Activities}

A hierarchy of income generating activities was created from the primary income generating activities women reported during the interview process. This hierarchy was constructed based on the amount of money earned per hour per week and the level of formality required. The money earned per hour per week for each activity was calculated using the data given in the interviews. For example, a female farmer earned approximately $29 \mathrm{KSH}$ per hour in a week while a female wholesaler earned approximately $1600 \mathrm{KSH}$ per hour per week. The formality of the job was determined by comparing structure of the workweek (days and hours worked each week), methods for gaining customers (finding customers versus having customers), and the overall regularity of the job (seasonal or not). The structure of the activity was compared to the other activities and a ranking system was created based on these three factors. For example, the least formal types of work include washing clothes and working on a farm due to the fact that income earned from these activities is sporadic, the hours are uncertain, and the customers vary by season. Thus, washing clothes and working on a farm income received a score of 1 . In contrast, working as a teacher provides a definite, consistent income, required hours, and guaranteed work. Therefore, teaching received a score of 6 . The full hierarchy is displayed in Table 2; each column lists relatively similar income generating activities in terms of amount of money earned and the formality of the work compared to the rest of jobs in that category.

Table 2. Hierarchy of income generating activities (IGA)

\begin{tabular}{|c|c|c|c|c|c|c|}
\hline $\begin{array}{l}\text { Lowest } \\
\text { IGA (1) }\end{array}$ & $\begin{array}{l}\text { Lower } \\
\text { IGA (2) }\end{array}$ & $\begin{array}{l}\text { Low-Middle } \\
\text { IGA (3) }\end{array}$ & $\begin{array}{l}\text { Middle } \\
\text { IGA (4) }\end{array}$ & $\begin{array}{l}\text { Middle-High } \\
\text { IGA (5) }\end{array}$ & $\begin{array}{l}\text { Higher } \\
\text { IGA (6) }\end{array}$ & $\begin{array}{l}\text { Highest IGA } \\
\text { (7) }\end{array}$ \\
\hline $\begin{array}{l}\text { Farm } \\
\text { Labor }\end{array}$ & $\begin{array}{l}\text { Wash } \\
\text { Clothes }\end{array}$ & Charcoal Seller & $\begin{array}{l}\text { Boutique } \\
\text { Seller }\end{array}$ & Employee & Teacher & Wholesaler \\
\hline \multirow[t]{4}{*}{ Hawker } & Cook & Food Vendor & $\begin{array}{l}\text { Market } \\
\text { Vendor }\end{array}$ & Tailor & $\begin{array}{l}\text { Business } \\
\text { Owner }\end{array}$ & \\
\hline & $\begin{array}{l}\text { Produce } \\
\text { Seller }\end{array}$ & & Salon & & & \\
\hline & & & Cereal & & & \\
\hline & & & Seller & & & \\
\hline
\end{tabular}

\subsection{Factors Influencing Job Choice}

\subsubsection{Education}

The Kenyan education system involves government-funded primary education for the first eight years of a students' schooling. Secondary education in Kenya usually includes four more years of courses, referred to as Form One through Form Four and a subsequent increase in school fees (Eshiwani, 1990). Only 28\% of the women interviewed continued beyond a primary education, with only $42 \%$ of them completing some level of secondary school. In addition to a low percentage of women obtaining a higher level of education, the data collected revealed that there might be little pay-off for women who find a way to fund and complete a higher educational level. A One-way analysis of variance (ANOVA) revealed no statistically significant difference in mean income among any of the education levels $(\mathrm{p}=0.878)$. There was however, a weak positive correlation (Pearson coefficient $=0.18, \mathrm{p}$-value $=0.016$ ) between education and income.

Figure 2 shows a box plot of total income as a function of education. In Figure 2 the $\mathrm{X}$-axis indicates the level of education a woman completed and the Y-axis indicates the average salary per month their work yields. "None" 
represents the women who received no formal education at all. "Primary" represents women who have completed some, if not all 8 years of a primary education. The "Secondary" on the chart represent women who have participated in some level of secondary education. What is startling about the data is that the middle $50 \%$ with a secondary education is very similar to the middle $50 \%$ of women with only a primary education. "College" represents the women who completed two more years of education beyond secondary. This usually means they studied specific trades like hotel management, tailoring, or cooking. This group does see a significant increase in salary, as they would find specific jobs with continuous salaries versus the previous groups who often had to come up with different entrepreneurial tactics to make a sustainable living.

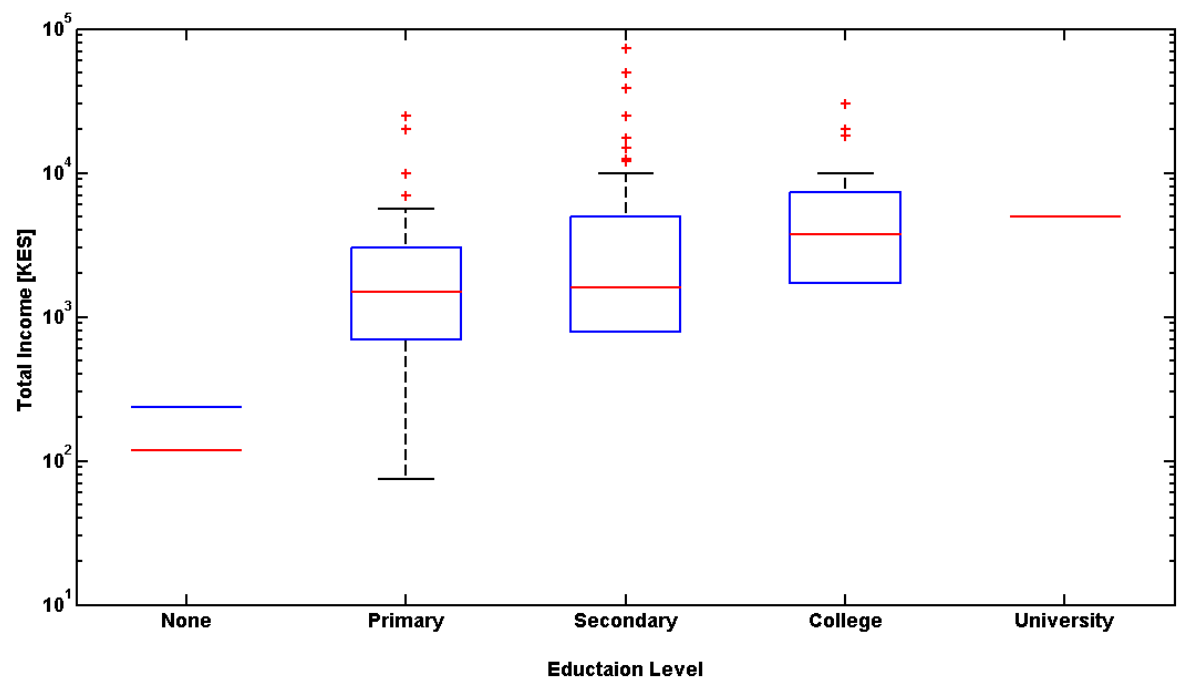

Figure 2. Relationship between educational level obtained and income

\subsubsection{Non-Income Related Benefits}

In respect to their chosen income generating activities, women widely reported that they valued the positive externalities associated with their activities above. For example, one produce seller in the Nyeri market explained, "It is not so bad. At the end of the day, if our food does not sell, at least we have something to bring home and eat." A different woman interviewed in the same market explained that even though the market was crowded with many women selling the same produce, she did not want to leave because "all of my friends are here"; she enjoyed going to work each day and being able to socialize with familiar people. This was similar to a clothes washer who washed clothes because down in the river "there are many of us together at the same time, doing the same thing." Finally, one woman in the used clothing market faced similar challenges to those in the produce markets: each plot is selling the same product and all are constantly hassled by the city council to pay their vendor fees. However, she said she enjoyed selling clothes because "I can sleep on them, it is a comfortable place to sit all day." Overall, women proved to be motivated by more than the economic benefits.

\subsubsection{Dependents}

Women reported highly valuing their relationships with their children and dependents. From the participant responses, 90\% reported they would rather spend their time and energy advancing their children or siblings' situations over advancing themselves. Women who were not university graduates widely expressed hopes that their children would attend university and obtain a job different from the one they, as the parent, engaged in. Observations revealed women, while sometimes in dire financial circumstance, tended to have an altruistic mind set towards their children.

A one-way ANOVA did show a statistically significant difference $(\mathrm{p}=0.020)$ among the average number of children for women working one job (2.67) and the average number of children working three jobs (4.00). There was also a weak $(r=0.237)$, but statistically significant $(\mathrm{p}=0.002)$ positive correlation between the number of children and the number of incomes. Along with this, there was a weak negative correlation (Pearson coefficient $=-0.198$, p-value $=0.010$ ) between the education and the number of dependents. The box plot illustrating this relationship is shown in Figure 3. 
As illustrated, there is a statistically significant slight positive correlation between the total number of dependents and the total number of activities engaged in, suggesting women are engaging in activities that are not very lucrative and, therefore, need to work more to provide for more people. There seems to be a belief that more jobs, rather than a better job, will provide significantly more money.

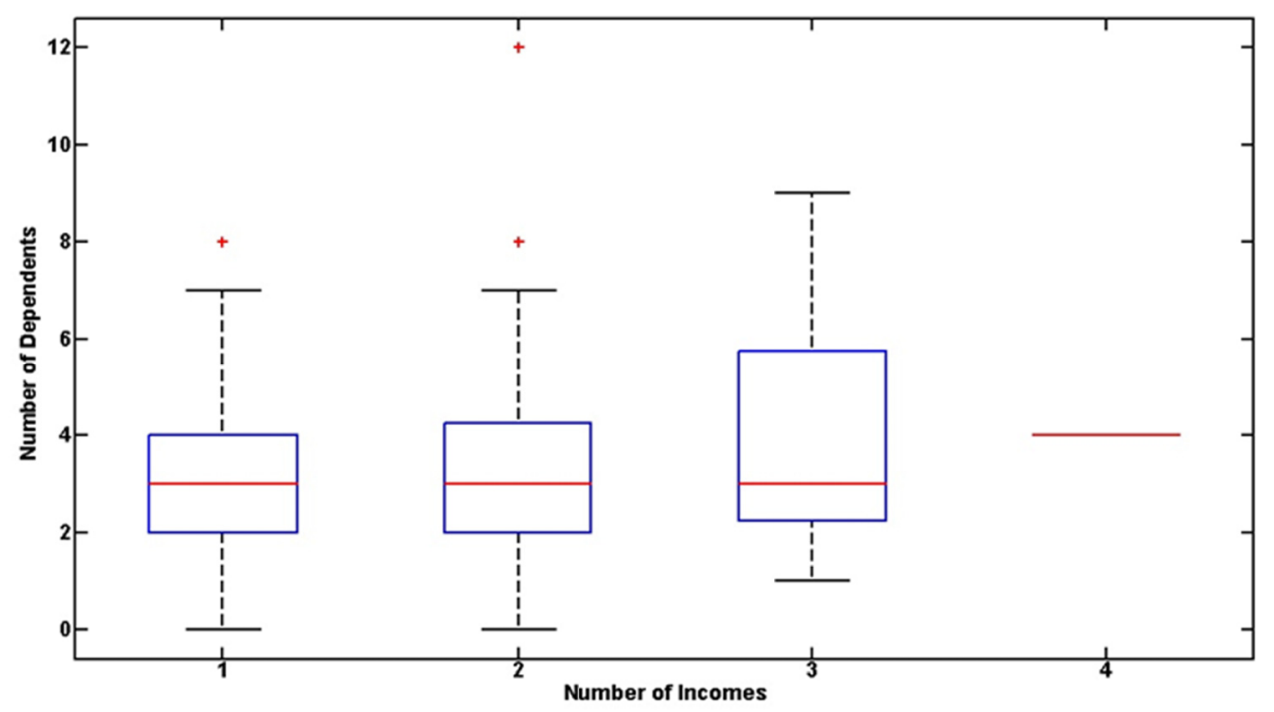

Figure 3. Relationship between number of dependents and number of income generating activities

\subsubsection{Multiplicity of Income Generating Activities}

Of the women interviewed, $34 \%$ reported engaging in at least two different income-generating activities. Of that $34 \%, 26 \%$ reported engaging in a third income-generating activity. As a result, the team hypothesized that working more jobs during the week lead to a distinctly higher income. A box plot of total income as a function of number of income-generating activities is shown in Figure 4.

The data analysis revealed that the median amount made by women who engaged in $1-3$ activities is relatively similar. There is also no significant difference in the mean incomes. However, variation occurs among the 75th percentile of each group. In other words, there is no guarantee that either working more jobs or fewer jobs will lead to more income earned each week. However, it is interesting that the range of incomes decreases with the number of income-generating activities which means engaging in more income generating activities does not necessarily mean higher income.

There is a slight negative correlation between the amount of money left over each week, for savings or disposable income, and the number of incoming generating activities a woman engages in. The Pearson's correlation coefficient for this correlation was -0.030 with a supporting p-value of $6.82 \mathrm{E}-05$. In other words, the amount of extra earnings decreases as the number of jobs worked increases. This reveals that women who are spending extra energy and time on multiple income generating activities are accruing less wealth, which may be contrary to what they believe. This may also mean that women who have no single stable income from a more formal job are forced to complete multiple different tasks to break even. 


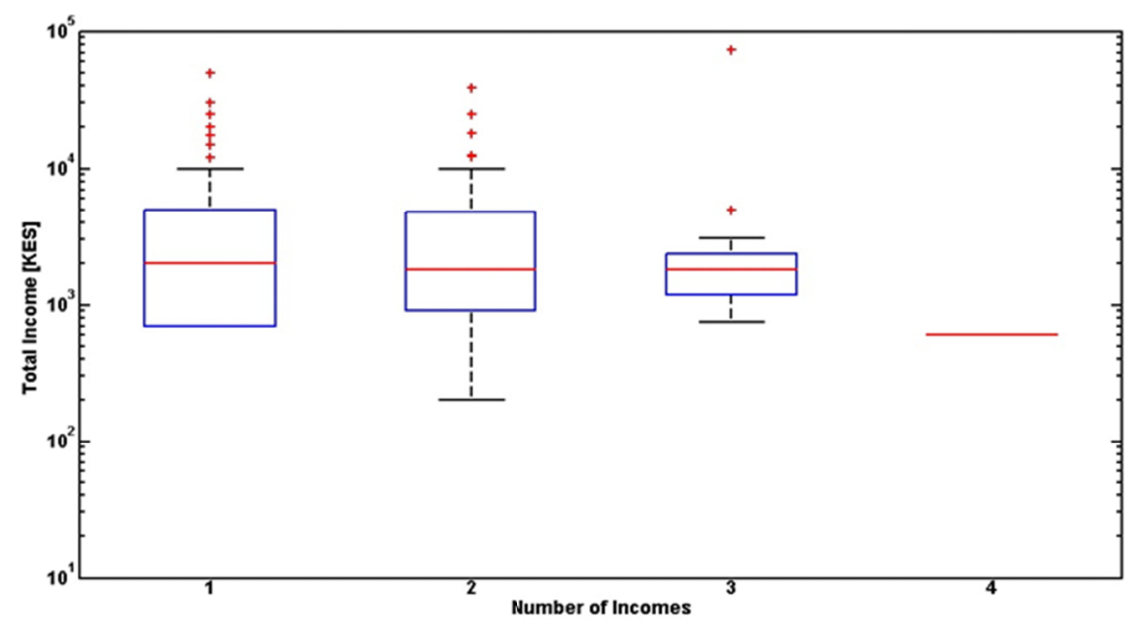

Figure 4. Relationship between income and number of income generating activities

\subsubsection{Dream Gap}

Qualitative data revealed that women could not see themselves engaging in a physically or economically different income-generating activity in the future and only $9 \%$ of respondents cited that they would be interested in starting their own business. For example, three women who sold charcoal only hoped to sell produce in the future. Both selling charcoal and selling produce require obtaining the product from a seller, sitting at a stand for long hours, and receiving few customers per day. Additionally, a woman who sells produce explained she only aspired to sell cereal. Observations revealed women rely on a day-to-day mind set instead of a long-term mind set.

From the observations it was hypothesized that a "dream gap" exists in the minds of rural Kenyan women; women do not aspire to reach a job that is more specialized or earns more money than the work they currently engage in. At the end of the study, data from all participants surrounding the current jobs they work and the jobs they aspire to work was analysed in a bubble graph. Income generating activities listed on the axes were categorized based on hours worked and income earned, as described previously. This bubble graph is seen in Figure 5. The size of the bubble represents the number of women with the job listed on the $\mathrm{x}$-axis that aspire to achieve the corresponding income generating activity on the y-axis.

The hypothesis of a "dream gap" could not be proved by the data gathered. If such a trend did exist, the bubbles would significantly increase as the y-axis increases. 


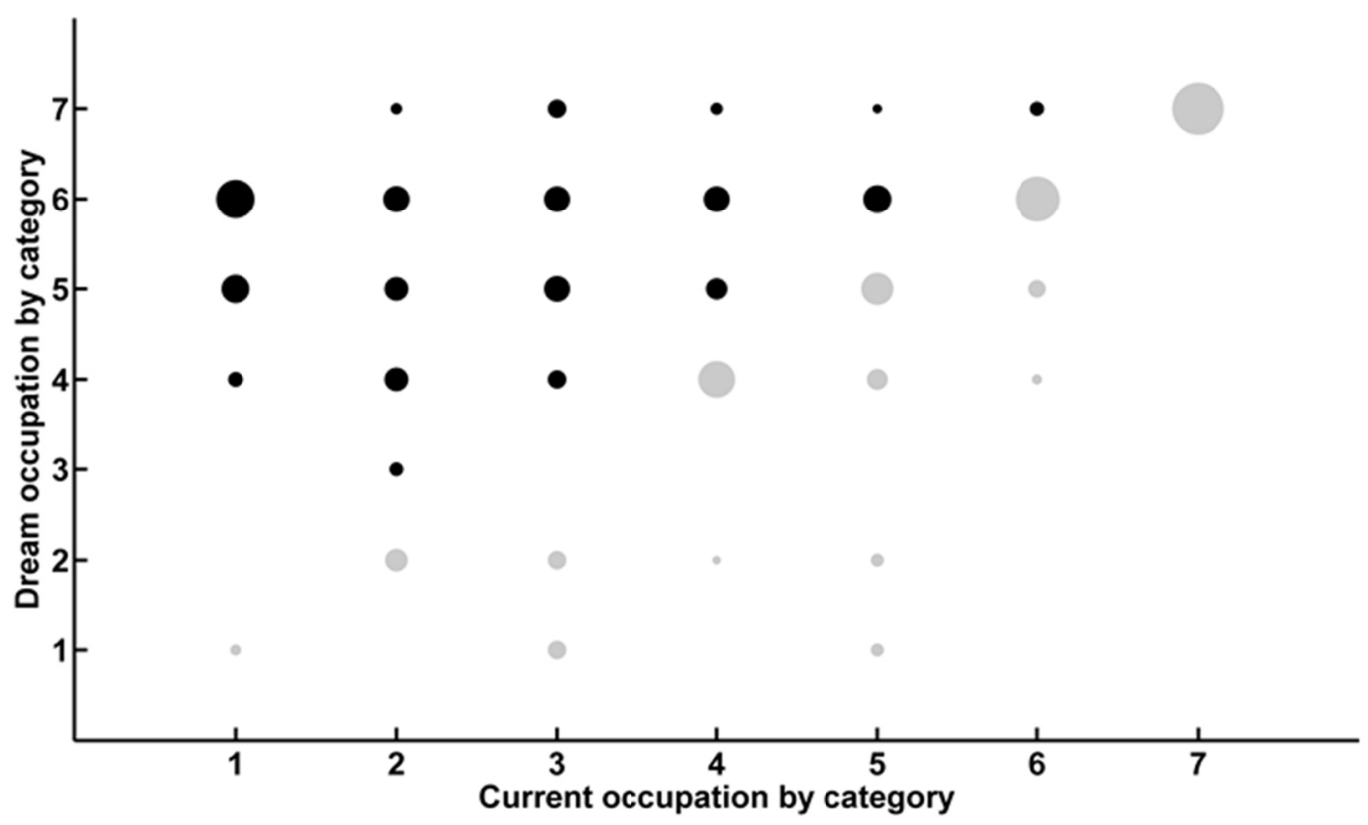

Figure 5. Relationship between current income generating activity engaged in and dream occupations based on constructed categories

\subsubsection{Rejection of Entrepreneurial Income Generating Activities}

Women cited the incurrence of extra expenses as the major reason for rejecting entrepreneurial income generating activities. One woman cited that " $[\mathrm{I}]$ work for someone in the market so I do not have to pay extra expenses." In addition, $83 \%$ of the women cited "capital" or "lack of money" as the major barrier for obtaining their dream job (regardless of whether the dream job was entrepreneurial in nature or not). Whether women needed capital to buy more produce to expand their plot in the market, buy more machines for their tailoring business, or go back to school to receive the training needed for their dream job, they did not have the disposable income to invest in developing a better career.

Finally, from our observations, there was a clear gender divide; women held certain jobs compared to men. For example, women were produce sellers in the market, clothing washers, salon workers, maids, tailors, and teachers while men worked in the lumberyards, as hawkers, matatu or piki-piki drivers, business owners, and cooks.

\section{Discussion}

Ultimately, the number of female-headed households is growing in East Africa, and as a result household dynamics and income generation activities are shifting (Meehan, 2004). Women face a number of challenges as they transition from household members to heads of household, the most significant being that they have to assume the additional role of primary wage-earner. Income generating activities, specifically entrepreneurial ventures, have proven to be a positive tool for sustainable development, but currently few women engage in this way (Holmes, 2). Though many participate in several income-generating activities at one time, women often find it difficult to maintain their livelihoods. Each type of work faces multiple, unique challenges such as obtaining adequate customers, attaining capital for growth, and balancing the time needed to earn an income while taking care of dependents.

To understand how to create and market the importance and benefit of entrepreneurial activities to these hard working women, it is important to understand the motivations and influences that impact their choice of work. This study analyzed the effect of prioritizing relationships over occupation, engaging in multiple types of work, providing for multiple dependents, and education level achieved. Statistically significant relationships were revealed between dependents and income, education and income, and the number of activities and income. By understanding the dynamics of these key factors of rural women's lives better opportunities for entrepreneurial engagement can be developed. This information can also be interpreted and used by both micro franchise and social franchise opportunities looking to empower women. These frameworks normally include providing loans 
and access to capital, tools, guidance, and credibility, but may not always consider the unique contexts and conditions of the women. Ensuring the success of women entrepreneurs in East Africa can be better accomplished with more relevant and tailored frameworks.

\section{Acknowledgements}

The authors would like to acknowledge and extend their sincere thanks to the Children and Youth Empowerment Center (CYEC) for their dedication and support for the project. Mercy, Peter, and Alex helped with data collection and translation for this study. The authors are grateful to the College of Engineering and the Presidential Leadership Academy at Penn State for providing financial support.

\section{References}

Alur, S., \& Schoormans, J. P. L. (2011). Sustainable rural healthcare and social franchisee selection: An India study. Journal of Medical Marketing: Device, Diagnostic, and Pharmaceutical Marketing, 11(3), 230-236. http://dx.doi.org/10.1177/1745790411411264

Bakesha, S., Nakafeero, A., \& Okello, D. (2009). ICTs as agents of change: A case study of grass-roots women entrepreneurs in Uganda. In Buskens \& Webb (Eds.), African Women and ICTs: Investigating Technology, Gender and Empowerment (pp 143-154). London: Zen Books Ltd.

Banerjee, A., \& Duflo, E. (2007). The economic lives of the poor. Journal of Economic Perspectives, 21, 141-168. http://dx.doi.org/10.1257/jep.21.1.141

Botha, M., Nieman, G., \& van Vuuren, J. (2007). Measuring the effectiveness of the Women Entrepreneurship Programme on potential, start-up and established women entrepreneurs in South Africa. South African Journal of Economic and Management Sciences, 10(2), 163-183.

Buvinic, M., Nadia, Y., \& Von Elm, B. (1978). Women-headed households: The ignored factor in development planning. Washington, D.C.: International Center for Research on Women.

Chant, S. (2008). Dangerous equations? How female - headed households became the poorest of the poor: Causes, consequences and cautions. In Momsen \& Janet (Eds.), Gender and Development: Critical Concepts in Development Studies. London: Routledge.

Cukier, W., Trenholm, S., Carl, D., \& Gekas, G. (2011). Social entrepreneurship: A content analysis. Journal of Strategic Innovation and Sustainability, 7(1), 99-119.

Eshiwani, G. S. (1990). Implementing educational policies in Kenya. World Bank Discussion Papers, Washington D.C.: The World Bank.

FAO. (2008). Mapping poverty, water and agriculture in sub-Saharan Africa. In Faurès \& Santini (Eds.), Water and the Rural Poor. Rome: FAO.

Francis, E. (2002). Gender, migration and multiple livelihoods: Cases from Eastern and Southern Africa. Journal of Development Studies, 38, 167. http://dx.doi.org/10.1080/00220380412331322551

IFAD. (1999). Human enterprise ecology: Supporting the livelihoods of the rural poor in East and Southern Africa. Main Report and Working Paper No 2. Rome: IFAD.

IFAD. (2011). The issue of poverty among female-headed households in Africa. IFAD.org. Web. 10 Aug 2014.

Jiggins, J. (1989). How poor women earn income in sub-Saharan Africa and what works against them. World Development, 17(7), 953-963. http://dx.doi.org/10.1016/0305-750X(89)90160-5

King, E., \& Lomborg, B. (2008). Women and development. Copenhagen: Copenhagen Consensus Center.

Meehan, F. (2004). Female headed household in Tigray, Ethiopia: A study review. Oslo: Drylands Coordination Group.

Quisumbing, A., \& Pandolfelli, L. (2009). Promising approaches to address the needs of poor female farmers: Resources, constraints, and interventions. World Development, 581-592.

Schreiner, M., \& Woller, G. (2003). Microenterprise development programs in the United States and in the

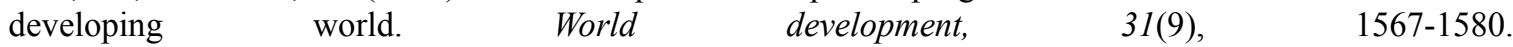
http://dx.doi.org/10.1016/S0305-750X(03)00112-8

Terjesen, S., \& Elam, A. (2012). Women entrepreneurship: A force for growth. International Trade Forum, 2, 16-17.

Terrell, K., \& Troilo, M. (2010). Values and female entrepreneurship. International Journal of Gender and 
Entrepreneurship, 2(3), 260-286. http://dx.doi.org/10.1108/17566261011079242

World Bank. (2009). World Development Report 2009. Washington, DC: World Bank.

World Bank. (2012). Women are less likely than men to participate in the labor market in most countries. Data. World Bank.org. Web. 30 Nov 2013.

Zulu, E. (2011). Overview of migration, poverty and health dynamics in Nairobi cities slum settlements. Journal of Urban Health, 88, 185. http://dx.doi.org/10.1007/s11524-011-9595-0

\section{Copyrights}

Copyright for this article is retained by the author(s), with first publication rights granted to the journal.

This is an open-access article distributed under the terms and conditions of the Creative Commons Attribution license (http://creativecommons.org/licenses/by/3.0/). 